\title{
Obtaiment of Pudu (Pudu pudu) deer Embryos by the Somatic Nuclear Transfer Technique
}

\author{
Obtención de Embriones de Pudú (Pudu pudu) Mediante \\ Técnicas de Transferencia Nuclear Somática \\ "Felipe Venegas; ** Michel Guillomot; **Xavier Vignon; **Jean-Luc Servely; **Chistophe Audouard; "Enrique Montiel; \\ ***Daniel Le Bourhis; ** Sandrine Perón; ****Pilar Soto \& *Mariana Rojas
}

VENEGAS, F.; GUILLOMOT, M.; VIGNON, X.; SERVELY, J-L-; AUDOUARD, C.; MONTIEL, E.; LE BOURHIS, D.; PERÓN, S.; SOTO, P. \& ROJAS, M. Obtaiment of Pudu pudu deer embryos by the somatic nuclear transfer technique. Int. J. Morphol., 24(2):285-292, 2006.

SUMMARY: The objective of this project is to produce pudu embryos, obtained by means of fibroblast transfer taken from the ear of one animal, to the oocytes of a domestic ruminant such as cattle. In further work, the pudu embryos will be transferred to the uterus of synchronized recipient females of another species.

Biopsies $1 \mathrm{~mm}$ in size were obtained from the outer rim of the ear of two male pudu deer belonging to the Buin Zoological park, Santiago, Chile. The cell lines have been established and kept according to protocols used in cattle. The oocytes are obtained through a puncture in the oocyte-cumulus complex (OCC) from cow ovaries recovered from the butcher. Each oocyte is enucleated and fused with an isolated fibroblast which is inserted beneath the pellucid zone. The fusion of cell membranes is achieved by means of electric shocks. In respect to the timetable, we have observed that a stage of two blastomers is reached on the second day, and morulae of 8 to 16 cells on the third day. On the fourth day it has differenciated as a blastocyst and on the seventh day it finally hacht from the pellucid zone. The obtainment of embryonic blastocytes indicates that it is possible to obtain pudu embryos through heterospecific cloning, even though the percentage of success is relatively low. The viability of the embryos obtained in this manner after in uterus transfer remains still to be verified.

KEY WORDS: Pudu deer; Cervidae; Ruminant; Cloning.

\section{INTRODUCTION}

The pudu (Pudu pudu) is the smallest of South American deer species; it reaches no more than $40 \mathrm{~cm}$ at the withers and weights less than $15 \mathrm{~kg}$ (Blumberg, 2002). It is a deer native to Chile and Argentine and can be found from sea level up to 1700 meters of altitude. In Chile it is distributed from $35^{\circ} 10^{\prime} \mathrm{S}$ (VII Region) to $46^{\circ} 45^{\prime} \mathrm{S}$ (XI Region). This species has been considered endangered in accordance with the Red Book from the World Union for Nature (U.I.C.N.) and the appendix 1 of the CITES (Glade, 1993).

This species has suffered from the gradual destruction of its habitat, poaching and chasing by feral dogs. At present the population can be found forming small isolated groups that cannot reproduce between them. As a consequence, the increased in-breeding has resulted in an increase in the death rate caused by genetic illnesses (Codeff, 1991 and Mella et al., 2002).

The Pudu is a ruminant belonging to the Order Artiodactyle, Family Odocoileinae, which incluyes the genders Hippocamelus and Pudu. In turn, two species belong to the gender Pudu: Pudu mephistophiles, which inhabits Perú and Colombia, and the southern pudu or Pudu pudu native of Chile and Argentine. The pudu has 70 chromosomes (Spotorno \& Fernández-Donoso, 1975 and Spotorno \& Walker, 2000).

Activity patterns of the pudu in its natural habitat have been studied (Wetterberg, 1972; Eldridge et al., 1987), as well as its behavior in captivity (Macnamara \& Eldridge, 1987 and Cortes et al., 1988). Studies have also been carried out in

* Laboratory of Compared Embryology; ICBM; Department of Anatomy and Developmental Biology; Medical School, University of Chile.

** Institut National de la Recherche Agronomique; Jouy en Josas; Francia.

**** Buin-Zoological Park, Santiago - Chile.

Grant ECOS-CONICYT C03 B02 
order to establish the relationship between $\mathrm{LH}$ and testosterone levels to the development of the antlers in the male deer $(\mathrm{Re}-$ yes et al., 1993).

The seasonal changes of the pudu testicles are also well known, as well as the variations of cortisol, IGF-1 and triodothyronine levels in males (Reyes et al., 1997). Other endocrine studies in adult males pudu, concerning the levels of FSH, LH, testosterone and prolactine in adult males have been published (Bubenik et al., 2000). Bartos et al. (1998) studied the hormonal levels of two males housed together with females, in order to assess dominance characteristics. By other hand, Hershkovitz (1982), reported that pudu have a gestational period of 7 months (between 202 to 223 days).

The publication by Schurer \& Sliwa (2002) provides much more information: the average length of gestation observed in this study was 210 days; the average weight at birth was $890 \mathrm{~g}$ (55 newborn animals were assessed), the female usually being as heavy as the males. Offspring below $600 \mathrm{~g}$ did not survive, nor did those weighing more than 1000 g Guzmán et al. (1986), described some characteristics of birth: the female gives birth to a single foal of reddish tabby color, with whitish stripes along the back and thighs. These stripes disappear at the age of three months.

The pudu placenta, like that of other deers is oligocotyledonary, villous, and epithelio-chorial. The placenta had only one intact cotyledon and a second atrophying cotyledon. The larger cotyledon observed measured 8 x $1 \mathrm{~cm}$. The placenta weighed $110 \mathrm{~g}$. There is intensive interdigitation of villi with the caruncular epithelial folds. Thus, an intimate contact between trophoblast and endometrial epithelium is established. The caruncles are composed of stroma and blood vessels, covered by endometrial epithelium. There are no glands (Harrison \& Hamilton, 1952; Hamilton et al., 1960; Sadlier, 1987 and Drion et al., 2003)

Although natural reproduction should be the preferred method in order to increase the population of a certain species, when wild populations are decreasing in number this is not longer possible. The pudu reproduction program developed by Reyes (1991) has been a contribution to the country but has not been able to improve the situation. Reproduction technology could be an important support by establishing genetic reserve banks of endangered animals in risk of extinction (Holt et al., 1996; Holt \& Pickard, 1999; Watson \& Holt, 2001 and Holt et al., 2002) and for the conservation of wild animals.

It is thought that reproduction of wild species could be aided by the use of stored genetic material (Wildt et al., 1997). from zoological parks and universities, specially those species at risk of extinction. These techniques include Artificial Insemination, Embryonic Transplant, In Vitro Fertilization and the intracytoplasmic injection of sperm cells (Comizzoli et al., 2000). At present, assisted reproduction technique is being fine-tunned in deer species. The "Proyecto Arca" in Argentina is an example. Their objective is to return the "father David's deer" (Elaphurus davidianus) to it's country of origin, not only because this species has become extinct in China, but because of the necessity of the development of a methodological work applicable to native deer.

Some zoos have successfully managed to keep pudus in captivity, as opposed to other south american endangered cervids such as the Taruca (Hippocamelus antisense) and the southern Huemul (Hippocamelus bisulcus), both of which species do not survive in captivity (Rojas et al., 2004, 2005). Hick (1969) reported the unsuccessful raising of a pudu at Cologne Zoo. Pudus are currently kept at Doué-la-Fontaine zoo in France and in the Wild Animal Park of the Zoological Society of San Diego, USA, where reproduction of the shouther huemul has been achieved. (Hershkovitz).

In South American zoos, banks with of pudu sperm are kept in order to aid artificial insemination of this species (Santiago Metropolitan Zoo, in Chile and also in Buenos Aires Zoo, Argentina). Diverse activities have been carried out in parallel to generate an increase in the reproduction rate in other vulnerable and endangered deer all over the world. Nevertheless, classic techniques of embryo production have proved to be difficult. From this point of view, Locatelly \& Mermillod (2005) stated that reproductive biotechnology and assisted reproduction methods in endangered cervids could help conservation programs.

Restoration of species by transfer of somatic nuclei into enucleated recipient oocytes has already been considered (Moratelli et al., 2002). Calves of an endangered breed of cattle (Enderby Island) adapted to extreme climatic conditions were born after nuclear transfer of granulose cells into enucleated oocytes from domestic cows and the ulterior transfer of the resulting embryos into domestic cow recipients (Wells et al., 1998, 2000). Additionally, a pregnancy was observed after the transfer of embryos reconstructed from cells of argali (Ovis ammon) and enucleated oocytes of domestic sheep (White et al., 1999). In the giant panda, blastocysts have also been obtained after nuclear transfer of panda cells into rabbit enucleated oocytes (Chen, 1999). Six day embryos of the Saola deer (Pseudoryx Nghetinhensis) have also been obtained by means of the cloning method and are currently kept frozen, waiting to be implanted on to a surrogate mother (Service Presse INRA).

Furthermore, it has been demonstrated that bovine oocyte cytoplasm could also be used as recipient for somatic 
cells from different mammalian species (Dominko et al., 1999). Cloning might even serve a useful purpose with species that have never bred in captivity, such as the saola (Comizzoli et al., 2000) y el huemul (Rojas et al., 2005).

The "Frozen Zoo" of CRES, at San Diego Zoo, (www.sandiegozoo.org) keeps fibroblast cell lines from a wide variety of cervid species, most of them including chromosomal analysis. In Chile and Argentina genetic material banks of different animals have also been established, in hope that once the technology is sufficiently advanced, the cloning of endangered animals could be achieved. However, no obtainment of pudu embryos have been reported to date, and neither has the obtainment of embryos from material kept frozen in liquid nitrogen.

The objective of this project is to produce pudu embryos, obtained by means of fibroblast transfer taken from the ear of one animal, to the oocytes of a domestic ruminant such as cattle. In further work, the pudu embryos will be transferred to the uterus of synchronized recipient females of another species.

From an ethical point of view, we must emphasize that our aim is to help conservation programs. The techniques to be used will not harm the pudu deers, nor cause any suffering. On the other hand, the pudu genome will be preserved, no other genes will be introduced and no genetic manipulation will be performed. The techniques used will have no incidence or alter the ecosystem.

\section{MATERIAL AND METHOD}

Biopsies $1 \mathrm{~mm}$ in size were obtained from the outer rim of the ear of two male pudu deer belonging to the Buin Zoological park, Santiago, Chile. The biopsies were placed on a sterile gausse, dampened in culture medium enriched in antibiotics and fungicide (nistatine) in order to be transported.
Once in the laboratory, the sample was shaved and rinsed to remove the loosen hairs. The sample was then placed on a culture dish were micro fragments of tissue were cut and deposited on a plate of 35 to $60 \mathrm{~mm}$ diameter. Culture medium $(1,5 \mathrm{ml}$ per $60 \mathrm{~mm}$ plate) was added to the border of the plate, and nistatine was added as a fungicide agent. Later, the culture plates were placed in an incubator at $38^{\circ} \mathrm{C}$ with a $5 \% \mathrm{CO} 2$ atmosphere. The cell lines have been established and kept according to protocols used in cattle (Vignon et al., 1998 and Bourc'his et al., 2001).

Re-sampling. The cells were washed twice with $\mathrm{PBS}$ at $37^{\circ} \mathrm{C}$. Then, for a $60 \mathrm{~mm}$ diameter culture plate, $1 \mathrm{ml}$ of $0.05 \%$ tripsine - EDTA $0.02 \%$ at $37^{\circ} \mathrm{C}$ was added. After three minutes at $37^{\circ} \mathrm{C}$, the reaction is stopped and the DMEM medium at $10 \%$ of SVF is added. After the first steps, the two cell types: fibroblasts and keratinocytes coexist on the same culture plate. In order to separate them, we used acutasse, according to the same protocol described for tripsine, to remove preferentially the fibroblasts during the first three minutes of enzymatic digestion. If the incubation time of the tripsine ( 3 minutes) are rigorously respected during the first 3 to 4 re-sampling, only the fibroblasts are separate while the keratinocytes remain adhered to the culture dish. The cells are controlled by observation under the phase-contrast microscope.

Cells from half of the plates were frozen, collecting the cellular precipitate with $450 \mu l$ of cow fetal serum and 50 $\mu l$ of DMSO (cryoprotector agent). Once the DMSO was added, the tube was quickly placed in a $-80^{\circ} \mathrm{C}$ freeze (step absolutely necessary to guarantee 90 to $95 \%$ survival). After 48 hours at $-80^{\circ} \mathrm{C}$, the cells were stored in liquid nitrogen.

Oocyte recovery from bovine ovaries. The oocytes are obtained through a puncture in the oocyte-cumulus complex (OCC) from cow ovaries recovered from the butcher. The oocytes are matured in vitro in the presence of FSH, LH and estradiol for 22 hours, at $39^{\circ} \mathrm{C}$.

Microinyection of the pudu fibroblasts into the enucleated bovine oocite. (Fig. 1).
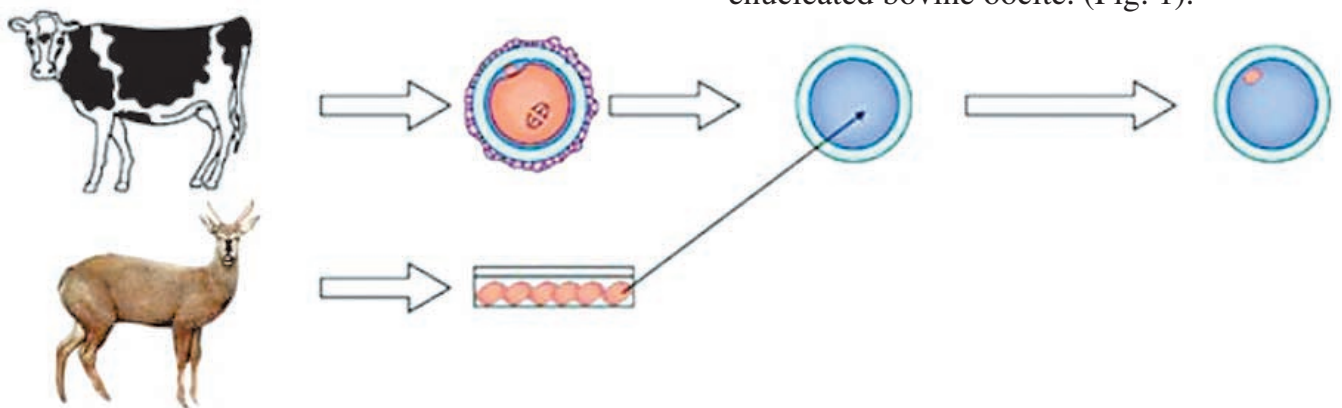

Fig. 1. An oocyte is obtained from a bovine female and is then enucleated with the aid of a micromanipulator. Simultaneously, pudu fibroblasts from the ear dermis are obtained, which are cultured for many generations. Then the entire fibroblast is inserted into the cytoplasm of the oocyte, beneath the pellucid zone to construct an embryo. 
The nuclei were microinjected using an Olympus mechanic micromanipulator into the cytoplasm of oocytes of deer species. Following the dechrorioning procedure, each oocyte is enucleated and fused with an isolated fibroblast which is inserted beneath the pellucid zone. The fusion of cell membranes is achieved by means of electric shocks. The reconstituted embryos thus obtained are cultured in the presence of nutritious cells (Vero) for a seven day period. This construction of pudu embryo by means of somatic nuclear transfer to bovine oocytes is performed according to the protocols established for bovine embryos.

\section{RESULTS}

The results obtained vary from one cellular line to another (See table 1). On a first experiment, cell nuclei isolated from the 4th stage of culture were transferred and only $9.5 \%$ of the reconstituted embryos reached the stage of 8 to 16 cells. On the contrary, when the nuclei come from the 6th stage of fibroblast culture, 53\% of the embryos developed to the 8 to 16 cell stage and even reached the blastocyst stage. The success reached a figure of $4 \%$.

In respect to the timetable, we have observed that a stage of two blastomers is reached on the second day, and morulae of 8 to 16 cells on the third day. On the fourth day it has differenciated as a blastocyst and on the seventh day it finally hacht from the pellucid zone (Fig. 2).

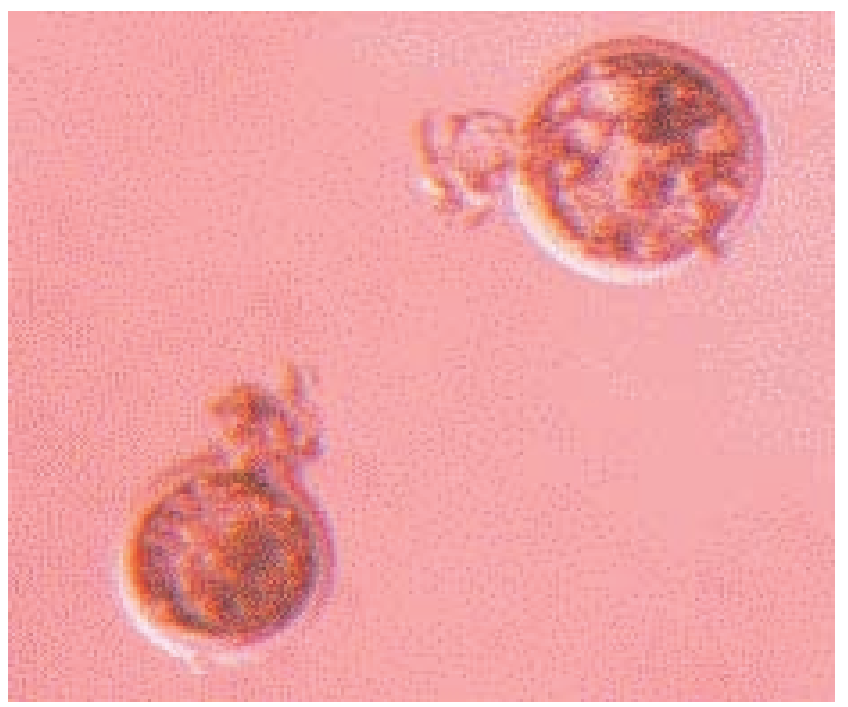

Fig. 2. On the seventh day a blastocyst hacht from the pellucid zone. $1000 \mathrm{X}$

The genetic origin of the embryos has been confirmed. Cariotype analysis of the blastocytes thus obtained shows that they present the same number of chromosomes as the pudu fibroblasts from which derivates $(n=70)$.

\section{DISCUSSION}

Berg \& Asher, 2003; Locatelly \& Mermillod have reported that the use of reproductive biotechnology in cervid species may help conservation programs. However, in the case of vulnerable or endangered animals, there is not availability of the adequate number of same specie oocytes and optimal females for embryonic transfer. Because of this, we have had to resort to interspecific nuclear transfer, using oocyte cytoplasm of another species.

In this research, the development of pudu embryos up to the blastocyst stage has been succesfully achieved and the embryos have begun the hatching stage. From the morphological and cariotype analysis points of view, the embryos are normal, although we do not know if the development timetable is normal, due the lack of studies were the development timetable for the first stages of pudu embryo is established.

If we compare our data to that from another deer such as the Cervus elaphus bactrianus that reaches the hatched blastocyte stage at 8 days (Peterson et al., 1997), we could conclude that the development of the first stages turned out to be very accelerated in the Pudu. The same occurs if the comparison is established to cattle, where the blastocyte stage is observed on the 7th day (Frei, 2004).

Bainbridge et al. (1998) indicate that the production of embryos and offspring depends on the existing knowledge of the reproductive physiology of each particular species. Little is known about the physiology and the timings of the first stages of pudu development. The use of cattle oocytes has resulted adequate for nuclear transference, which is in agreement with what is informed by Dominko et al. (1999), who clearly demonstrated that bovine oocyte cytoplasm, could also serve as recipient for somatic cells from different mammalian species.

The main problem of interspecific nuclear transfer occurs in the first generation and it is due to the mitochondria issue previously described. However, it is worthwhile to point out that if the nucleus comes from the male individual of the species of interest the reconstructed embryo, and even more, the first generation may present mitochondria from both species. This problem can be overcome if the cloned male reproduces naturally with a female of the species of interest, because the paternal mitochondria are not transmitted to the next generation. This argument cannot be applied to the female because the mitochondria are inherited through the maternal cytoplasm ( Da-Yuan et al., 2002; Holt et al., 2004). Studies are necessary in order to determine the effect of 


\begin{tabular}{|c|c|c|c|c|c|c|c|}
\hline \multirow[t]{3}{*}{ Cells* } & \multirow[t]{3}{*}{ Fusion } & \multirow[t]{3}{*}{$\begin{array}{c}\text { Reconstructed } \\
\text { Embryos (\%) }\end{array}$} & \multicolumn{5}{|c|}{ In Vitro Development } \\
\hline & & & Day $2(\%)$ & Day 3(\%) & Day $4(\%)$ & Day $5(\%)$ & Day $7(\%)$ \\
\hline & & & 2 cells & $8-16$ cells & Bl. & Bl. & HatchedBI \\
\hline $\mathrm{p} 4$ & 60 & $42(70)$ & $11(26)$ & $4(9,5)$ & 0 & 0 & 0 \\
\hline p6 & 55 & $47(85)$ & $32(68)$ & $25(53)$ & $2(4)$ & 2(4) & $2(4)$ \\
\hline
\end{tabular}

Table I. Number of cloned embryo obtained after Pudu fibroblast nucleus transfer to bovine oocytes.

$*$ Cell culture time; $\mathrm{p} 4=4$ th stage $; \mathrm{p} 6=6$ th stage. $\mathrm{Bl}=$ blastocyst.

heterologous mitochondria in the pudu deer, both in blastocytes and in the first generations.

Although our success percentage of $4 \%$ seems to be relatively low, it is quite adecuate if one considers that we are dealing with deer where the rate of development up to the blastocyte stage is less than $10 \%$ in in vitro produced embryos (Locatelly \& Mermillod). On the other hand, in the sika deer, a blastocyte after in vitro fertilization has never been observed. (Comizzoli et al., 2001). If we consider these facts as well as the fact that the most successful in vitro fertilization work has been the one carried out by Locatelly et al. (2005) on the Cervus elaphus, obtaining a $13 \%$ success in clivated eggs up to the blastocite stage, we may consider our results to be significantly good.

The application of reproductive biotechnology for the preservation of endangered mammalian species is limited by several factors. Wild species are more sensitive to stress as compared to domestic ones. An optimal genetic management system would consist of a captive population and a cryopreserved genetic resource bank in constant dynamic interaction (Wildt et al., 1997; Comizzoli et al., 2000). In this study, we have used pudu deer from a zoo, submitted to a minimal degree of stress and that showed no sign of any kind of problems.

Reproduction by cloning could be one of the methods used to increase the number of individuals in a population. It is well known that populations with low numbers of individuals poses a minimal genetic variation, but if some of the individuals fail to reproduce, a loss of genetic variation will occur. According to Holt et al. (2004) a possibility for small populations could be to clone each individual (not impossible if the population size is between 9-18 animals), this allows the offspring to grow, mature and reproduce in a natural way. The probability of loss of genetic variation can be reduced, especially if every parent gives rise to two identical copies of itself. This is an interesting theoretical model for animal conservation.

One of the problems of this technique being applied in conservation programs is the introduction of alien genetic material by means of the mitochondrial DNA of the bovine receptor oocyte. This risk can be considerably minimized if oocytes from filogenetically close species are used. Comparison of the use of bovine oocytes to those of another deer species such as (Dama dama) will be performed in following studies and also the evaluation of the embryonic development after being transferred to the uterus of the recipient females.

Several species of deer have become farm animals, especially so with the advent of a complete understanding of their reproductive physiology. Thus, Fletcher (2001) gives examples of farming of Cervus elaphus, C. e. canadensis, Dama dama and D. d. mesopotamica, with successful embryo transfer and other artificial breeding techniques. In Chile, this could be an important objective to achieve.

\section{CONCLUSIONS}

The obtainment of embryonic blastocytes indicates that it is possible to obtain pudu embryos through heterospecific cloning, even though the percentage of success is relatively low. The viability of the embryos obtained in this manner after in uterus transfer remains still to be verified.

ACKNOWLEDGEMENTS: to Buin-Zoological Park, Santiago - Chile. 
VENEGAS, F.; GUILLOMOT, M.; VIGNON, X.; SERVELY, J-L-; AUDOUARD, C.; MONTIEL, E.; LE BOURHIS, D.; PERÓN, S.; SOTO, P. \& ROJAS, M. Obtención de embriones de pudú ( $P u d u$ pudu) mediante técnica de transferencia nuclear somática. Int. J. Morphol., 24(2):285-292, 2006.

RESUMEN: Los objetivos de este trabajo fueron los de producir embriones de pudú, obtenidos por la transferencia de núcleos de fibroblastos de la oreja de pudú en ovocitos de un rumiante domésticos que es el bovino. Para posteriormente en un trabajo futuro proceder a la transferencia de embriones de pudú, al útero de hembras receptoras sincronizadas de otra especie.

Se obtuvieron biopsias de $1 \mathrm{~mm}$ aproximadamente del borde externo de la orejas de dos ciervos pudu machos del jardín zoológico Buin-Zoo, Santiago de Chile. Las líneas celulares han sido establecidas y conservadas según los protocolos utilizados para las bovinos. Los ovocitos son obtenidos por punción del complejo cúmulos-ovocito (COC).desde ovarios de vacas recuperados del matadero. Cada ovocito es enucleado y fusionado con un fibroblasto aislado insertado bajo la zona pelúcida. La fusión de membranas celulares es obtenida por choques eléctricos.

En cuanto a la cronología, observamos que al segundo día se forma una etapa de dos blastómeras, al tercer día mórulas de 8 a 16 células, y desde el cuarto día se ha diferenciado como blastocisto, el cuál al séptimo día termina por eclosionar de la zona pelúcida La obtención de blastocistos embrionarios indica que es posible obtener embriones de pudú mediante clonaje heteroespecífico, aunque, el porcentaje de éxito obtenido es relativamente bajo. Queda aun por verificar la viabilidad de los embriones así obtenidos después de la transferencia in útero.

PAlabras ClaVE: Pudu pudu ; Ciervos; Rumiante; Clonación.

\section{REFERENCES}

Bainbridge, D. R. \& Jabbour, H.N. Potential of assisted breeding techniques for the conservation of endangered mammalian species in captivity: a review. Vet. Rec., 143: 159-8, 1998.

Bartos, L.; Reyes, E.; Schams, D.; Bubenik, G. \& Lobos, A. Rank dependent seasonal levels of IGF-1, cortisol and reproductive hormones in male pudu (Pudu puda). Comp. Biochem. Physiol. A Mol. Integr. Physiol., 120:373-8, 1998.

Berg, D. K. \& Asher, G. W. New developments reproductive technologies in deer. Theriogenology, 59:189-205, 2003.

Blumberg, C. A. Contemplando aves y mamíferos de Aisén. Univ. de Los Lagos, Coyhaique, 2002.

Bourc'his, D.; Le Bourhis, D.; Patin, D.; Niveleau, A.; Comizzoli, P.; Renard, J.P. \& Viegas-Pequignot E. Delayed and incomplete reprogramming of chromosome methylation patterns in bovine cloned embryos. Curr. Biol., 11 (19):1542-6, 2001.

Bubenik, G. A.; Reyes, E.; Schams, D.; Lobos, A. \& Bartos, L. Pudu, the smallest deer of the world: 10 years of endocrine studies of southern pudu (Puda puda) in Chile. Z. Jagdwiss., 46:129-38. 2000.
Chen D.Y., The giant panda (Ailuropoda melanoleuca) somatic nucleus can dedifferentiate in rabbit ooplasm and support early development of the reconstructed egg, Science in China, Serie C. Life Sci., 42:346-53, 1999.

Cell lines are available from CRES at the San Diego Zoo under: www.sandiegozoo.org

CODEFF Informe sobre la captura, comercio y tenencia en cautividad de pudú (Pudu puda) en Chile. Comité Nacional Pro Defensa de la Fauna y Flora. 1991.

Comizzoli, P.; Mermillod, P. \& Mauget, R. Reproductive biotechnologies for endangered mammalian species. Reprod. Nutr. Dev., 40:493-504, 2000.

Comizzoli, P.; Mauget, R. \& Mermillod, P. Assessment of in vitro fertility of deer spermatozoa by heterologous IVF with zona-free bovine oocytes. Theriogenology, 56:26174, 2001.

Cortes, I. R.; Angulo, A. O.; Guzman, R. \& Reyes, E. Comportamiento del pudú (Pudu puda Molina) en cautiverio (Mammalia, Cervidae). Gayana Zoologia, 52:3-14, 1988.

Da-Yuan Chen; Duan-Cheng Wen; Ya-Ping Zhang; QingYuan Sun; Zhi-Ming Han; Zhong-Hua Liu; Peng Shi; Jin-Song Li; Jing-Gong Xiangyu; Li Lian; Zhao-Hui 
Koua; Yu-Qi Wu; Yu-Cun Chen; Peng-Yan Wang \& HeMin Zhang. Interspecies Implantation and Mitochondria Fate of Panda-Rabbit Cloned Embryos. Biology of Reproduction 67:637-42, 2002.

Dominko, T.; Mitalipova, M.; Haley, B.; Beyhan, Z.; Memili E.; McKusick, B. \& First, N. L. Bovine oocyte cytoplasm supports development of embryos produced by nuclear transfer of somatic cell nuclei from various mammalian species. Biol. Reprod., 60:1496-502, 1999.

Drion, P. V.; Hanzen, C.; Wirth. D.; Beckers, J. F.; Leboeuf, B.; Ropstad, E.; Balligand, M.; Bauvir, E.; Gabriel, A. \& Collin, B. Physiologie de la reproduction et endocrinologie chez les cervidés: une revue. Ann. Méd. Vét., 147:291-313. 2003.

Eldridge, W. D.; Macnamara. M. M. \& Pacheco, N. V. Activity patterns and habitat utilization of pudus (Pudu puda) in south-central Chile. Pp. 352-70 in Wemmer, C. M. (Ed) Biology and management of the Cervidae. Smithsonian Institution Press, Washington, DC, 1987.

Fletcher, T. J. Farmed deer: new domestic animals defined by controlled breeding. Reprod. Fertil. Dev., 13:511-16, 2001.

Frei, M. Desarrollo embrionario in vitro de ovocitos bovinos fecundados con espermatozoides adheridos al cumulus. Tesis de Grado en Ciencias Veterinarias. Universidad Católica de Temuco, 2004.

Glade, A. Libro Rojo de los Vertebrados Terrestres de Chile. CONAF, Santiago, Chile, 1993. 65 pp.

Guzmán, R.; Santa María, A.;Cox, J.; Reyes, E.; Angulo, A. $\&$ Hermosilla, I. Descripción de parto en pudú (Pudu pudu). Agrociencia, 2 (2):175-8, 1986.

Hamilton, W. J.; Harrison, R. J. \& Young, B. A. Aspects of placentation in certain cervidae. J. Anat., 94:1-23, 1960.

Harrison, R. J. \& Hamilton, W. J. The reproductive tract and the placenta and membranes of Père David's deer (Elaphurus davidianus Milne Edwards). J. Anat. 86:20324, 1952.

Hershkovitz, P. Neotropical Deer (Cervidae). Part I. Pudus, Genus Pudu Gray. Fieldiana. Zoology, New Series \# 11, 1982. pp. 86.

Hick, U. Successful raising of a pudu Pudu pudu at Cologne Zoo. Int. Zoo Yearbk., 9:110-2, 1969.
Holt, W. V.; Bennett, P. M.; Volobouev, V. \& Watson, P. F. Genetic resource banks in wildlife conservation. $J$. Zoology, 238:531-44, 1996.

Holt, W. V. \& Pickard, A. R. Role of reproductive technologies and genetic resource banks in animal conservation. Reviews in Reproduction, 4:43-150, 1999.

Holt, W. V.; Pickard, A. R.; Abaigar, T. \& Cano, M. Integrated approaches to the establishment of genetic resource banks for endangered gazelles. Proceedings of the 9th International Symposium on Spermatology, Cape Town. pp 127-132. Eds G Van der Horst, D Franken, R Bornman, T Bornman \& S Dyer. Bologna, Monduzzi Editore, 2002.

Holt, W; Pickard, A. \& Prather, R. Wildlife conservation and reproductive cloning. Reproduction, 127:317-24, 2004.

IUCN Red List of Threatened Species. Available online at http://www.redlist.org/. 2004.

Locatelli, Y. \& Mermillod, P. Caractéristiques et maîtrise de la fonction de reproduction chez les cervidés. INRA Prod. Anim., 18 (1):3-25, 2005.

Locatelli, Y.; Cognie, Y.; Vallet, J. C.; Baril, G.; Verdier, M.; Poulin, N.; Legendre, X. \& Mermillod, P. Successful use of oviduct epithelial cell coculture for in vitro product production ion of viable red deer (Cervus elaphus elaphus) embryos. Theriogenology, 64:1729-39, 2005.

Macnamara, M. \& Eldridge, W. Behavior and reproduction in captive pudu (Pudu puda) and red brocket (Mazama americana), a descriptive and comparative analysis. In, Biology and Management of the Cervidae, C.M. Wemmer, ed. Smithsonian Institution Press, Washington, DC, 1987.

Mella, J.; Simonetti, J A.; Spotorno, A. E. \& Contreras. L. C. Mamíferos de Chile. Pp 151-183. En G. Ceballos y J. A. Simonetti (eds.) Diversidad y Conservación de los Mamíferos Neotropicales. CONABIO-UNAM, México, 2002.

Moratelli, R.; Andrade, C. de M. \& de Armada, J. L. A technique to obtain fibroblast cells from skin biopsies of living bats (Chiroptera) for cytogenetic studies. Genet. Mol. Res., 30;(2):128-30. 2002.

Peterson, A. J.; Ledgard A. M. \& Berg, D. K. Conceptus development and associated fertility in red deer (Cervus 
elaphus) from days 11 to 25 after mating. Theriogenology, 47(1): 402-7, 1997.

Reyes, E. Programa para la conservación del ciervo chileno Pudu puda (Molina). Revista del Instituto de Ecología de Chile, 10:18-21, 1991.

Reyes, E.; Munoz, P.; Recabarren, S.; Torres, P. \& Bubenik, G. A. Seasonal variation of LH and testosterone in the smallest deer, the pudu (Pudu puda molina) and its relationship to the antler cycle. Comp. Biochem. Physiol. Comp. Physiol., 106:683-5, 1993.

Reyes, E.; Bubenik, G. A.; Schams, D.; Lobos, A. \& Enriquez, R. Seasonal changes of testicular parameters in southern pudu Pudu pudu in relationship to circannual variation of its reproductive hormones. Acta Theriologica 42:25-35,1997.

Rojas, F.; Venegas; Servely, J. L. \& Guillomot, M. Clonación, producción de quimeras y células pluripotenciales. Int. J. Morphol., 22 (4):343-50, 2004.

Rojas, F.; Venegas, E.; Montiel, J. L.; Servely, X.; Vignon \& Guillomot, M. Attempts at applying cloning to the conservation of species in danger of extinction. Int. J. Morphol., 23(4):329-36, 2005.

Sadlier, R. M. F. S. Reproduction in female cervids. In: Wemmer C. M. (Ed). Biology and Management of the Cervidae. Smithsonian Institution Press, Washington, 1987. 577pp.

Schurer, U. \& Sliwa, A. Sudpudus (Pudu pudu) in zoologischen Garten. Bongo, 32:3-11, 2002.

Spotorno, A. E. \& Fernández-Donoso, R. The chromosomes of the Chilean dwarf deer "pudu" Pudu pudu (Molina). Mammalian Chromosome Newsletter, 16:17, 1975.

Spotorno, A. E. \& Walker, L. Origen y evolución de los mamíferos chilenos. Pp 217-27, En: Mamíferos de Chile. Muñoz-Pedreros, A. \& Yañez, J. CEA, Valdivia, Chile, 2000. 464 pp.

Vignon, X.; Chesne, P.; Le Bourhis, D.; Flechon, J. E.; Heyman, Y. \& Renard, J. P. Developmental potential of bovine embryos reconstructed from enucleated matured oocytes fused with cultured somatic cells. CR. Acad. Sci. III. 321:735-45. 1998

Watson, P. F. \& Holt, W. V. Cryobanking the Genetic Resource. Wildlife Conservation for the Future? p 463.
London and New York, Taylor \& Francis, 2001.

Wells, D. N.; Misica, P. M.; Tervit, H. R. \& Vivanco, W. H. Adult somatic cell nuclear transfer is used to preserve the last surviving cow of the Enderby Island cattle breed. Reprod. Fertil. Dev., 10:369-78, 1998.

Wells, D. N. Cloning for animal conservation. Cloning 2: $15-5,2000$.

Wetterberg, G. B. Pudu in a Chilean National Park. Oryx 11:347-51. 1972 .

White, K. L.; Bunch, T. S.; Mitalipov, S. \& Reed, W. A. Establishment of pregnancy after the transfer of nuclear transfer embryos produced from the fusion of argali (Ovis ammon) nuclei into domestic sheep (Ovis aries) enucleated oocytes. Cloning, 1:47-54, 1999.

Wildt, D. E.; Rail, W. F.; Critser, J. K. \& Monfort, S. L. Seal US. Genome resource banks: living collections for biodiversity conservation. Bioscience, 47:689-98, 1997.

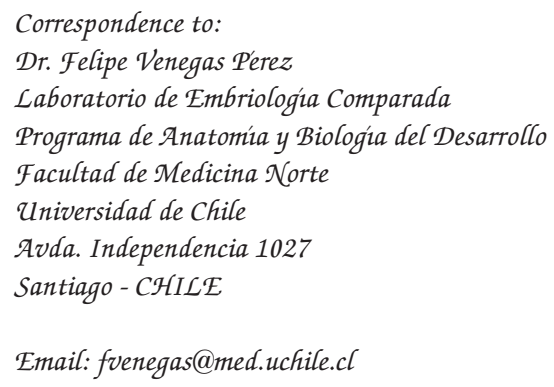

Received: 15-01-2006

Accepted: 02-05-2006 